\title{
The Organization of Community-Based Disaster Risk Reduction for the Earthquake and Tsunami in Bengkulu Province
}

\author{
Sri Indarti \\ Public Administration Doctoral Program \\ Faculty of Social and Political Science \\ Diponegoro University, Semarang, Indonesia
}

Sri Suwitri

Public Administration Doctoral Progam

Faculty of Social and Political Science

Diponegoro University, Semarang, Indonesia

Ir. Suharyanto

Public Administration Doctoral Progam

Faculty of Social and Political Science

Diponegoro University, Semarang, Indonesia

\section{Kismartini}

Public Administration Doctoral Progam

Faculty of Social and Political Science

Diponegoro University, Semarang, Indonesia

Received: January 25, 2017 Accepted: March 18, 2017 Published: March 22, 2017

doi: 10.5296/jsss.v4i2.10970 URL: http://doi.org/10.5296/jsss.v4i2.10970 


\section{Abstract}

Bengkulu province is located on the West Coast of Sumatra island, where a number of 7 out of 10 District/City of Bengkulu province is located in the coastal area. Vulnerability to earthquake, tsunami and Goro (tsunami) increases with the Bengkulu position has a complex geological structure because it is on the collision of two massive tectonic plates that is the Indo-Australia plate in the South and North of Eurosia marked with examples of tectonic earthquake centers on Enggano Islands, Laish and surrounding areas. Vulnerability is also due to the presence of a buffer is not yet a strong news/good natural fortification of mangrove, beach and spruce beach tree nor adequate breakwater. The research method is qualitative, which focuses on the research field. Data collection is done by observation, interview and documentation, research analysis conducted using an interactive model of Miles and Huberman, the validity of the data refer to the criteria of kredibitas Moleong with the validity of the analysis methodology policies from Dunn that focuses on triangulation, and with rolling according to needs also techniques utilizing of the other validity. The results showed that there are some PRBBK implementers such as BPBD with the village of Tough Social Service disaster, through disaster preparedness, Kampong program health services of villages program with active standby, PMI with the community-based disaster preparedness program (KBBM) and PRBBK along with Public Interest Group. The organization development of the upcoming PRBBK on needs to be improved by optimizing the role of each stakeholder and partnership organizer who combined with leadership, coordination by BPBD Province in which the head of the BPBD province (ex officio) is the Secretary of the County that has the authority to divide the Echelon task and coordinating the PRBBK.

Keywords: Community-based Disaster risk reduction (PRBBK), Earthquake and Tsunami

\section{Introduction}

The disaster is one of natural phenomena, which can't be eliminated completely, but can be reduced by reducing its impact damage on society and environment. The disaster impact closely related to choices made in managing the human and cultural environment, in building houses, government capacity, learning at school and those choices are made, all of which can make the vulnerability or resilience against disasters. Disaster management in recent decades is carried out in a comprehensive manner with focusing paradigm on disaster risk reduction knows as (PRB), which flourished in the international institutions and policies of the State policy, and has spread to the regional scope.

Since the late 1990s, the world increasingly recognizes the need for "mainstream" for disaster risk reduction knows as (PRB) into development, i.e. taking into account and pay attention to the risk-the risk of natural hazards in drawing up the strategic framework and institutional structure of the medium-term strategy and policy of the State and sectoral as well as in the design of projects in countries that are prone to danger. A number of agencies engaged in the field of development has begun efforts to mainstream disaster risk reduction into their work by doing a variety of institutional change, the related policies and procedures as well as adjusting their operational practices. (Benson \& Twigg, 2007).

Indonesia also have systematic agendas relate to disaster relief, including the existence of a policy of disaster management into Constitutional Laws No. 24 in 2007, followed by the 
decision of the head of BNPB No. 5 in 2010, of the national action plan for disaster risk reduction (RAN-RPB) in 2010-2011. The implementation mechanism of the disaster relief plan with the National Action Plan for disaster risk reduction (Renas-PRB) stated in Renas PRB 2010-2012, that "the mechanism of implementation of the RAN-PRB 2010-2012 is one unit with Renas-PB which has a period of five years, while RAN-PRB is a technical document that is more operational, timed three years".

PRB's statement echoed in various opportunities in Indonesia, especially after the various disaster came hammering, such as earthquake and tsunami in Aceh, earthquake in Yogya, Earthquake in Bengkulu, tsunami in Pangandaran, Earthquake in Padang, floods and landslides that hit different areas, and other disasters. Pramusinto said:

"The question of the disaster that used to only be a issue that is ruled out now mnejadi the central issues that cannot be detached from the Mission of our State, the issue concerned the question of not just catastrophic physical concerns how earthquake magnitudes, where the epicenter was, how much damage to buildings and others. The disaster is the question of public administration and pulic policy "(Pramusinto et al., 2009).

The era of regional autonomy provides opportunities for the region to more independently and efficiently utilize all its potential for service and the well-being of peoples in the regions. The main paradigm of disaster relief with the PRB has experienced decentralisation, with the establishment of BPBD in the area, the chance of the creativity programmes according to their local wisdom, and all the potential in the area. Bengkulu earthquake vulnerability against can have fused with the everyday life of the Bengkulu community. The Head Observation Section and Information of Agency for Meteorology, Climatology and Geography in Bengkulu province revealed earthquake following:

".. almost every day the earthquake occurred-a small earthquake. However the community are suggested not to worry because the presence of a small earthquake earthquake-it would be better to appear to anticipate the energy concentration of the earthquake. With the earthquake-a small earthquake below 5 SR means earthquakes have often issued the energy so that it will minimize the appearance of a larger earthquake ... the earthquake often based in Muko-Muko, Laish, Bintuhan and Enggano, ... Since January-March 2011, this has happened 7 times with the strength of earthquakes above 5 SR. from January to March was recorded almost every day the earthquake occurred. "(Another Bengkulu, March 9, 2011:5) 


\section{Macrothink}

Tectonic map with a geological structure in which Bengkulu can be seen in this figure

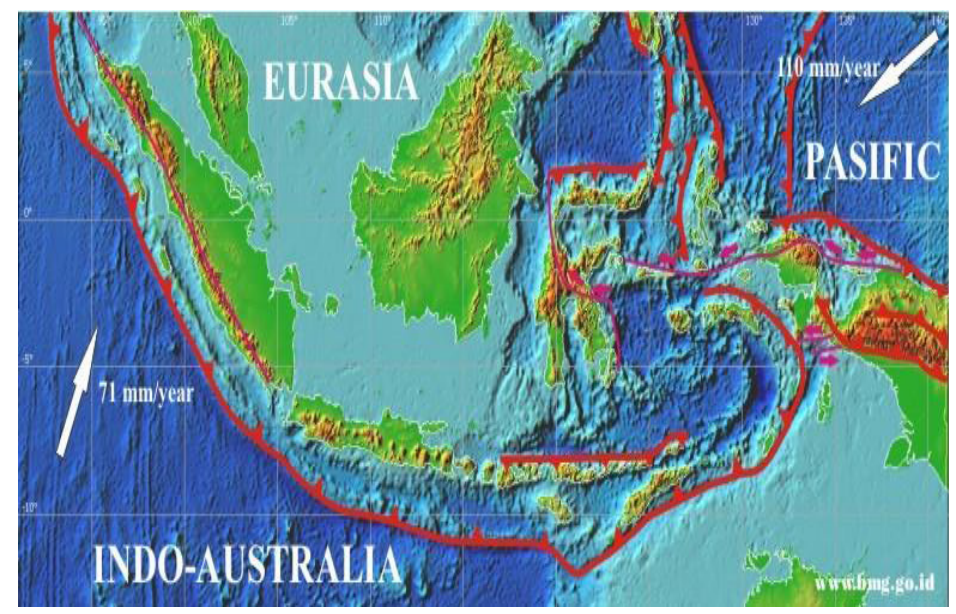

Source: Map Tectonic condition of Indonesia, Directorate for disaster risk reduction, the BNPB 2010:1

\section{Reserch Design}

\subsection{Disaster Risk Reduction Management}

Disaster relief management constantly done to minimize the impact of loss and disaster. A disaster can cause a lot of casualties and the huge losses, due to lack of understanding of the people against the characteristics of hazards (hazards), attitude or behavior that results in a decrease in the quality of the natural resources (vulnerability), lack of information/warning (early warning) that causes the unpreparedness and vulnerability/inability to face the threat of danger. Disaster risk reduction has a historical dimension, which suggests that prevention and kesiap-siagaan is the instinct of mankind since antiquity.

"Disasters are something inseparable in creature history. Humans struggled and continue to struggle in order to be free from disaster (free from disaster). In that struggle, mitigasi practice was born, such as flood mitigation, mitigation of drought (drought mitigation), and others. In Egypt, drought mitigation practices already are over 4000 years old. The concept of early warning systems for famine (famine) and kesiap-siagaan (preparedness) and giant barns prepared for seven years of abundance and first used during seven years of drought are already born in $2000 \mathrm{BC}$, “(Wikipedia).

Changing times, knowledge and scientific discoveries resulted in a paradigm shift from conventional to holistic headed in disaster relief. Disaster relief policy paradigm started to pre disaster, when a disaster occurs and after experiencing the development paradigm as follows:

a. Relief/emergency relief Paradigm

b. Mitigation Paradigm

c. Paradigm Development

d. risk reduction Paradigm

(Bakornas disaster relief, 2007:4)

The focus of the paradigm of risk reduction declared by the national disaster management 
coordination board as follows:

... The latter paradigm is a paradigm of risk reduction. This approach is a combination of a technical and scientific point of view with attention to factors social, economic and political planning in disaster reduction. In this paradigm of disaster management aims to improve the ability of communities to manage and suppress the risk of occurrence of the disaster. The most important thing in this approach is to look at society as a subject and not objects of disaster mitigation in the development process. (Bakornas disaster relief, 2007:5).

The paradigm of a more comprehensive disaster management namely the paradigm for disaster risk reduction, which combines a threat/vulnerability and insecurity with the capability as a unity that can not be separated. Disaster risk reduction known as (PRB) is an important aspect in kesiap-siagaan's response to the disaster, which was carried out in the Center and developed in these areas. Local authorities are instrumental to perform the mobilization of a wide array of good resources to reduce disaster risk, through capacity building institutional policy implementers, building community resilience, strengthening or complementing the diverse means of risk reduction.

\subsection{Community-Based Disaster Risk Reduction known as (PRBBK)}

Community-based Disaster risk reduction known as (PRBBK) or Community Based Disaster Risk Reduction known as (CBDRR) is an approach that encourages grass-roots communities in conducting its own interpretation over the threats and risks facing disaster, perform priority handling/disaster risk reduction faced, reducing as well as monitor and evaluate its own performance in disaster reduction efforts (see Paripurno in UNDP, 2012). Then Abarquez \& Murshed in Lassa (2008) States, PRBBK can also didefnisikan as "the empowerment of the community to be able to manage disaster risk with the level of involvement of the parties/community groups in the planning and utilization of local resources in implementation activities by the communities themselves.

PRBBK contain the need for participation, so ideally approach is bottom up approach. Top down approach can be done when the initiation or facilitation activities at the beginning of PRBBK. But over time the msyarakat prepared for the independent, so it will be more dominant mechanism of bottom up. In addition, the presence of integration requires PRBBK in development, ranging from the smallest sphere (villages) and the scope of the next (sub district, region or city and so on). In the era of reform and decentralization, then integration PRBBK largely determined by the commitment of the local authorities in the development process.

Thus PRBBK is the process of internalization of PRB present vulnerable community participatory designed by optimizing the use of local resources, to build the Foundation of safety and security, which was developed as part of the development process on an ongoing basis.

\subsection{The Model Of Conducting Community-Based Disaster Risk Reduction known as (PRBBK)}

The model is an abstraction of the real world, substitution, or the representation of reality in the form of such plots, map, diagram of the Organization, and other mathematical equations, which is used as a tool when dealing with the real phenomena of complex and expensive if it is examined directly. The model is also a natural way to obtain a description of the real world 


\section{Macrothink}

by studying the replicas which reflect the phenomenon (Quade, 1989). Thus the Model kegiatanpada the substance is visualization or conceptual framework that is used as a guide in meiakukan activities. The model becomes a means to simplifies the understanding of something, the description factually from a series of steps or set of activities.

The model developed in the conducting of PRBBK uses a model system, which its analysis to a synergy with the Community model of Korten and Reinventing Government - banishing bureaucry theory systems from Howard. Collaborative analysis and model development is expected to be able to produce a model management system form PRBBK by optimizing the interaction component of society, programs and organizations that work together with all other resources in the process of learning to achieve conformity with each other. Strategies for change in society is through community-based resource management (community-based resource management). Management system on a PRBBK projected to develop all resources which varied with the principles of the Government's strategy with renventing banishing bureucracy, so can doptimalkan empowerment organization that is supported by the concept of leadership.

Models that can be used for the implementation of community-based program is a Model of a system, a Model System of Reinventing Government and banishing bureaucry. Systems theory became an important part of applied studies and public administration, as the Administration's own country is a system. In its analysis, the systems approach requires any with model and the appropriate analysis techniques. (Ibrahim, 2009). Systems thinking (Systems Thinking) in fact thought by making use of understanding and approach to the system. In the dinamikanya, think the system includes a set of methods, tools and principles "rather not", all of which are oriented to look at kesalingterikatan between forces and saw it as part of a joint process. (Bateson et al., in Senge et al., 2001).

The model of this system can be described as follows:

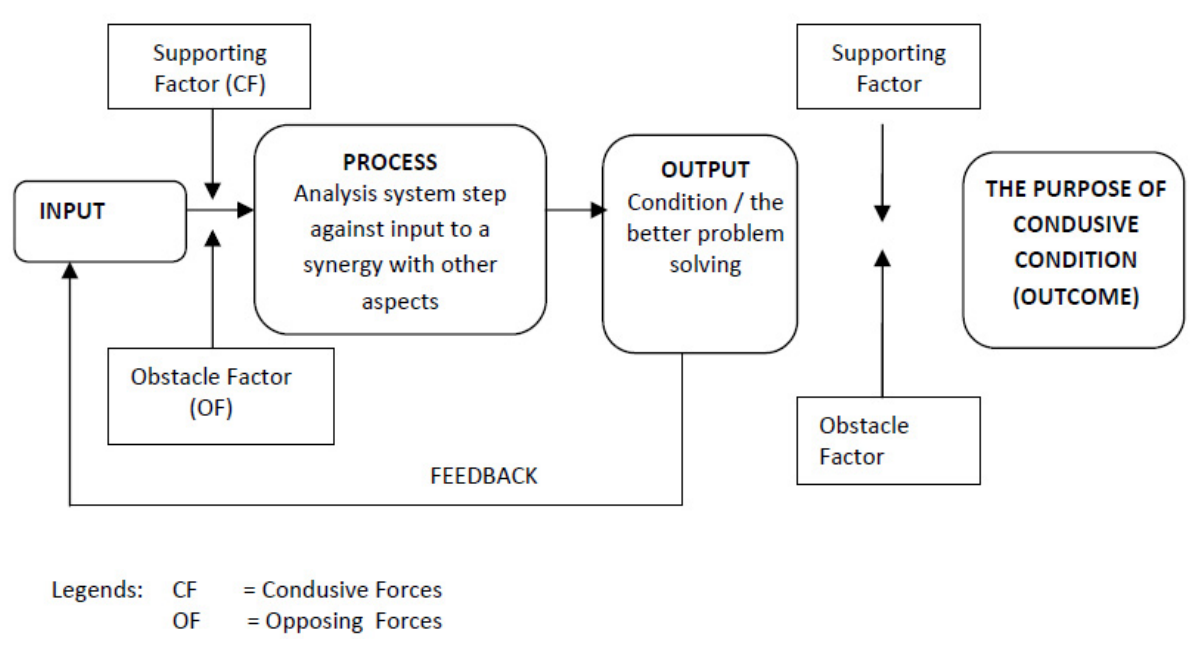

Figure 1. Model System (source: adaptation from Ibrahim, 2009) 


\section{MInstitute ${ }^{\text {Macrothink }}$}

\section{Research Method}

This research is qualitative research, which focuses on the research field. Data collection is done by observation, interview and documentation, peneitian analysis conducted using an interactive model of the Miles and Huberman, who has three principal processes are: data collection, data reduction, the presentation of the data and conclusions-withdrawal/verification. The validity of the data in this study refer to the criteria of kredibitas Moleong with the validity of the methodology of the analysis of the policy of Dunn (2007) which in general have characterized the multiplisisme crisis and the decision is a fundamental methodological triangulation. Applicative in the validity of the data of this research focuses on the triangulation, as aspects of credibility and with rolling according to needs also use techniques-techniques other validity according to needs and conditions, which include, transition, ' reliance and certainty. Triangulation is done by checking the correctness of the data by comparing data obtained with data from other sources. Method triangulation refers to the use of different data collection instruments, either direct observation, kuisener, interviews and other instruments.

\section{Discussion}

\section{A. Small Earthquake And Tsunami In Bengkulu Province}

Vulnerability to tsunami or the small tsunami (tidal wave) that could endanger people, the loss of property and diverse resources most communities in Bengkulu the higher, because there is no buffer zone (barrier) natural or artificial zones to protect coastal community. Vulnerabilities in catastrophe that befell with Bengkulu, has led to the loss of damage due to the earthquake, such as the earthquake on April 10, 2016 and June 2, 2016 of Bengkulu province, among which there are in the picture below:
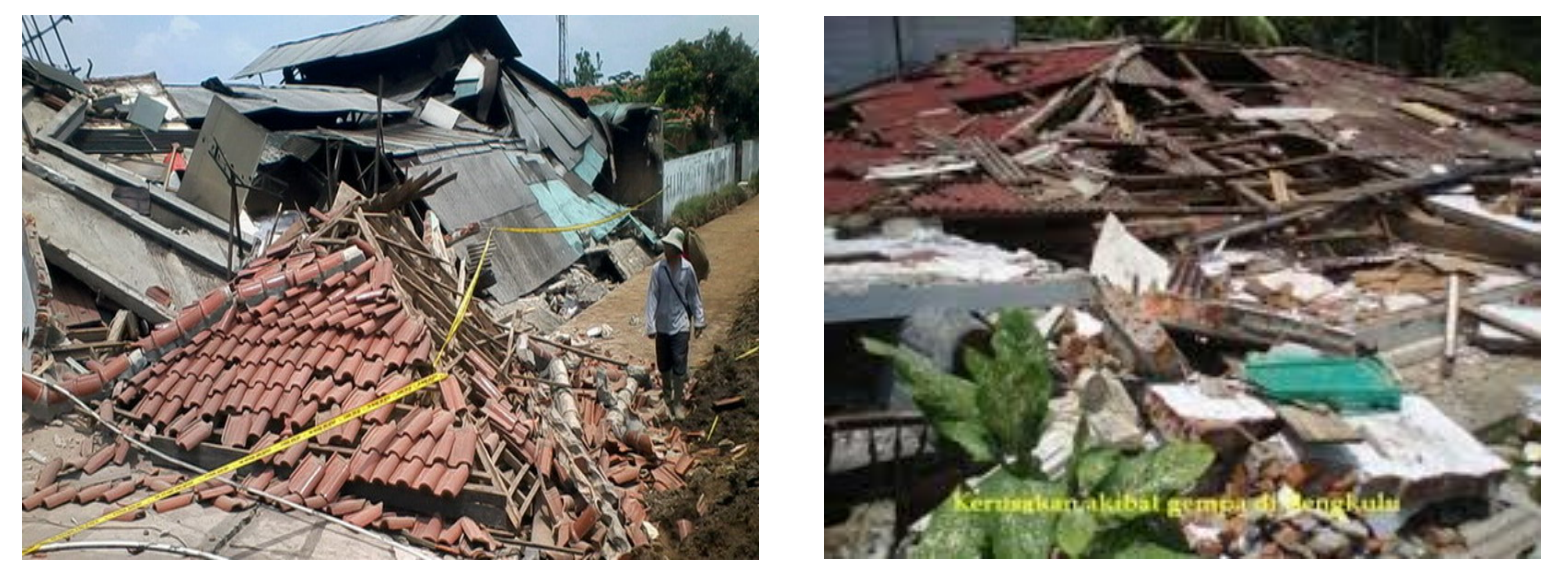

Figure 2. Damage to houses as the impact of the earthquake was April 10, 2016 in Pekan Sabtu District Bengkulu city (sumber: bpbd.bengkuluprov.go.id)

Damage to residential of Muko-Muko Regency due to the earthquake of June 2, 2016, including the following: 


\section{Macrothink Institute ${ }^{\mathrm{TM}}$}
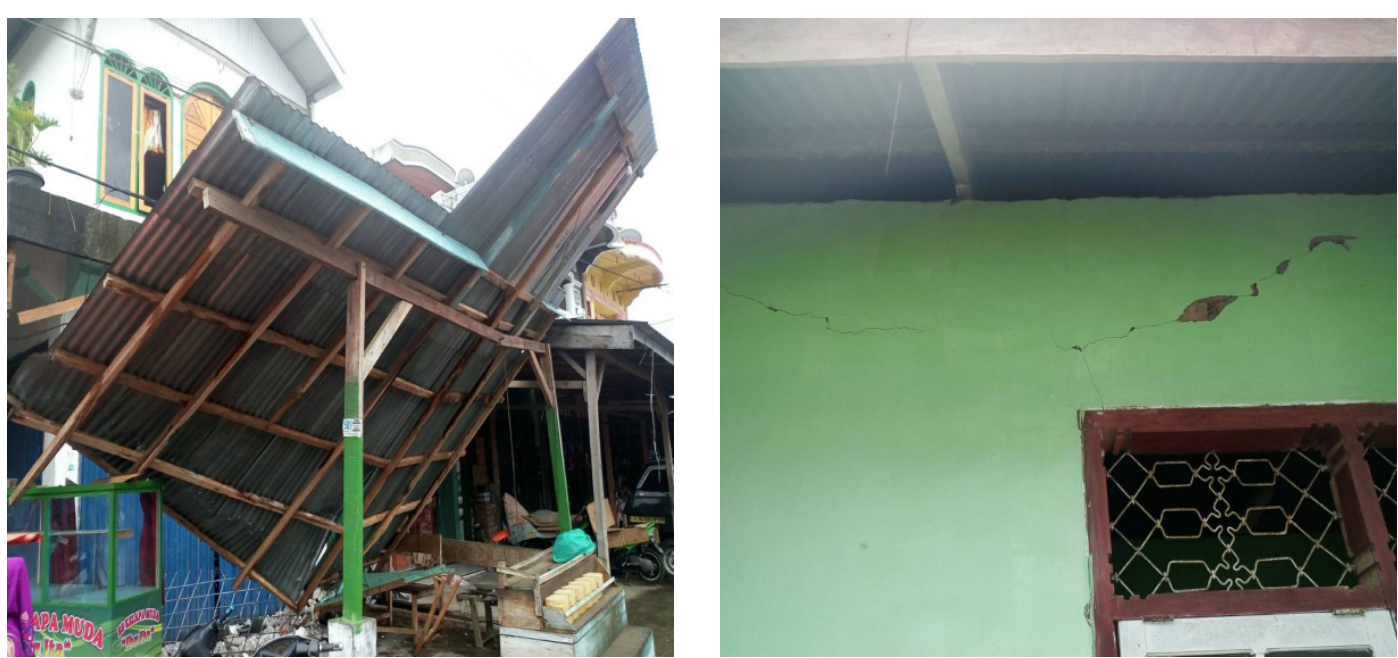

Figure 3. Most houses in Muko-Muko Regency damaged by the earthquake of June 2, 2016 (source: Documentation Archives of MDMC Bengkulu)
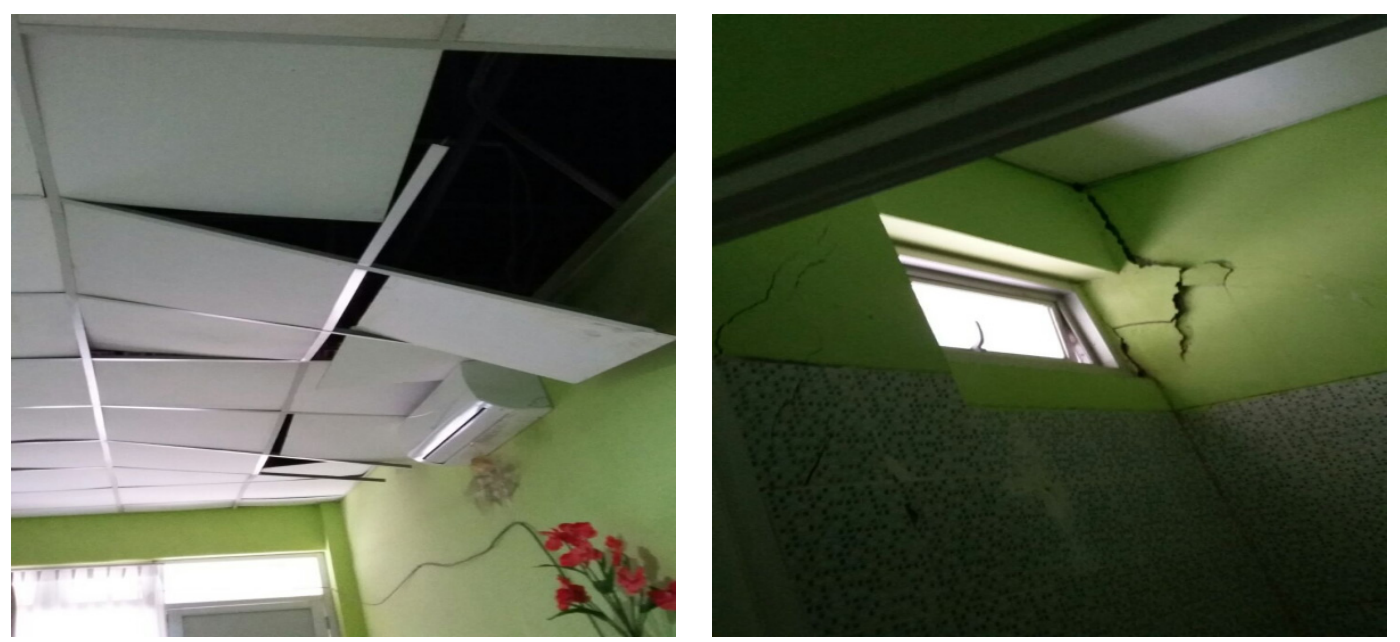

Figure 4. Damage to most space Muko-Muko Regency RSU earthquake June 2, 2016. (Archives of MDMC Bengkulu, June 2, 2016)

A small earthquake and tsunami events (Goro) in Bengkulu province in the period March to September 2016can be seen in the following table: 
Table 1 Incidence of Big Earthquake and Small Tsunami in March-September 2016 in Bengkulu Province

\begin{tabular}{|c|c|c|c|}
\hline $\begin{array}{l}\text { Date } \\
\text { Hour }\end{array}$ & Disaster & $\begin{array}{l}\text { High and } \\
\text { Deepness }\end{array}$ & Location \\
\hline $\begin{array}{l}\text { March 2, } \\
\text { 201619:49:41 } \\
\text { WIB }\end{array}$ & Earthquake & $\begin{array}{l}\text { Mag:8,3 SR } \\
\text { The depth is } 10 \\
\mathrm{~km} \\
\text { Having potential } \\
\text { Tsunami }\end{array}$ & $\begin{array}{l}\text { 5.16 LS, 94.05 BT } \\
\text { (682 km Southwest of Mentawai Island) }\end{array}$ \\
\hline $\begin{array}{l}\text { March 29, } \\
2016 \\
13: 24: 00 \mathrm{WIB}\end{array}$ & Earthquake & $\begin{array}{l}\text { Mag:5,5 SR } \\
\text { The depth is } 182 \\
\mathrm{~km}\end{array}$ & $\begin{array}{l}2.95 \mathrm{LS}, 102.16 \mathrm{BT} \\
(22 \mathrm{~km} \text { of the West Lebong Region } \\
\text { Bengkulu Province }\end{array}$ \\
\hline $\begin{array}{l}\text { April 10, } 2016 \\
\text { 09:14:33 WIB }\end{array}$ & Earthquake & $\begin{array}{l}\text { Mag:5,9 SR } \\
\text { The depth is } 16 \\
\mathrm{~km}\end{array}$ & $\begin{array}{l}\text { 4.32 LS, } 102.09 \text { BT } \\
\text { (61 km Southwest Bengkulu, Bengkulu) }\end{array}$ \\
\hline $\begin{array}{l}\text { April 10, } 2016 \\
\text { 10:07:00 }\end{array}$ & Earthquake & $\begin{array}{l}\text { Mag: } 4,8 \mathrm{SR} \\
\text { The depth is } 20 \\
\mathrm{~km}\end{array}$ & $\begin{array}{l}\text { 4.45 LS, } 102.07 \text { BT } \\
(84 \mathrm{~km} \text { Southwest Seluma Region of } \\
\text { Bengkulu Province }\end{array}$ \\
\hline Mai 16, 2016 & Earthquake & Mag: 6,1 SR & $\begin{array}{l}\text { 2,79 LS, 101,99 BT } \\
\text { (63 km Southeast Muko-Muko dan } 51 \mathrm{~km} \\
\text { Northwest of North Bengkulu) }\end{array}$ \\
\hline $\begin{array}{l}\text { Mai 30, 2016, } \\
\text { 7:16:07 WIB }\end{array}$ & Earthquake & $\begin{array}{l}\text { Mag 4,4 SR } \\
\text { The depth is } 5 \\
\mathrm{~km}\end{array}$ & $\begin{array}{l}\text { 3.41 LS, } 102.51 \mathrm{BT} \\
\text { (1 km Curup- Bengkulu) }\end{array}$ \\
\hline $\begin{array}{l}\text { June } 2,2016 \\
\text { 05:56:01 WIB }\end{array}$ & Earthquake & $\begin{array}{l}\text { Mag:6,5 SR } \\
\text { The depth is } 72 \\
\mathrm{~km}\end{array}$ & $\begin{array}{l}2.29 \mathrm{LS}, 100.46 \mathrm{BT} \\
\text { ( } 79 \mathrm{~km} \text { Southwest of the South Coastal } \\
\text { Sumbar or } 115 \text { Northwest Muko-Muko } \\
\text { Bengkulu) }\end{array}$ \\
\hline June 2, 2016 & $\begin{array}{l}\text { Small } \\
\text { Tsunami }\end{array}$ & $\begin{array}{l}\text { The waves } \\
\text { incoming to the } \\
\text { lands and } \\
\text { settlement }\end{array}$ & Muko-Muko District Bengkulu Province \\
\hline $\begin{array}{l}\text { June 19, } 2016 \\
04: 15 \text { WIB }\end{array}$ & Earthquake & $\begin{array}{l}\text { Mag: } 5,4 \mathrm{SR} \\
\text { The depth is } 54 \\
\mathrm{~km}\end{array}$ & $\begin{array}{l}3.26 \mathrm{LS}, 101,31 \mathrm{BT} \\
\text { (66 km Southwest Muko-Muko Bengkulu } \\
\text { Province) }\end{array}$ \\
\hline July 12,2016 & Earthquake & $\begin{array}{l}\text { Mag:5,3 SR } \\
\text { The depth is } 72\end{array}$ & $\begin{array}{l}\text { 4.82 LS, } 102.07 \mathrm{BT} \\
(111 \mathrm{~km} \text { Southwest of Seluma Region }\end{array}$ \\
\hline
\end{tabular}




\begin{tabular}{|c|c|c|c|}
\hline & & $\mathrm{km}$ & Bengkulu Province) \\
\hline $\begin{array}{l}\text { July } 23,2016 \\
14.41 .00 \text { WIB }\end{array}$ & & $\begin{array}{l}\text { Mag:5,6 SR } \\
\text { The depth is } 10 \\
\mathrm{~km}\end{array}$ & $\begin{array}{l}-6,68 \mathrm{LS}, 101,16 \mathrm{BT} \\
\text { (334 km Southwest of South Bengkulu } \\
\text { Region) }\end{array}$ \\
\hline $\begin{array}{l}\text { August } \\
2016\end{array}$ & e & $\begin{array}{l}\text { Mag 5,5,SR } \\
\text { The depth is } \\
140 \mathrm{~km}\end{array}$ & $\begin{array}{l}\text { 5.72 LS, } 100.57 \text { BT } \\
\text { ( } 284 \text { kilometers southwest of Bengkulu, } \\
\text { near Seluma Regency and Enggano Island } \\
\text { North Bengkulu Regency) }\end{array}$ \\
\hline $\begin{array}{l}\text { August } \quad 18, \\
2016 \\
\text { 18.35:00 WIB }\end{array}$ & Eal & $\begin{array}{l}\text { Mag: } 4,1 \mathrm{SR} \\
\text { The depth is } 27 \\
\mathrm{~km}\end{array}$ & $\begin{array}{l}\text { 4.33 LS, } 102.18 \mathrm{BT} \\
\text { ( } 60 \mathrm{~km} \text { south of Bengkulu city /near Tikus } \\
\text { Island) }\end{array}$ \\
\hline $\begin{array}{l}\text { August } \\
2016\end{array}$ & Eartl & $\begin{array}{l}\text { Mag:5,8 SR } \\
\text { The depth is } 21 \\
\mathrm{~km}\end{array}$ & $\begin{array}{l}2.95 \mathrm{LS}, 100.07 \mathrm{BT} \\
(155 \mathrm{~km} \text { Southwest of Muko-Muko } \\
\text { Regency Bengkulu Province) }\end{array}$ \\
\hline $\begin{array}{l}\text { September } 17 \text {, } \\
2016 \\
09: 30: 53 \text { WIB }\end{array}$ & Earthquake & $\begin{array}{ll}\text { - } & \text { Mag 5,4 SR } \\
\text { - } & 19 \mathrm{~km}\end{array}$ & $\begin{array}{l}\text { 4.79 LS, } 102.49 \mathrm{BT} \\
(79 \mathrm{~km} \text { Southwest of South Bengkulu } \\
\text { Regency) }\end{array}$ \\
\hline
\end{tabular}

Source: BMKG, MDMC Bengkulu, Antara.com.

\section{B. The Implementation Of Prbbk Eartquake And Tsunami In Bengkulu Province}

\section{- Disaster Resilient Village}

Disaster Resilient villages was villages that have independent ability to adapt and deal with the potential threat of disasters, as well as recovering quickly from the impact of the adverse impact of disasters -. (Perka BNPB No.1 in 2012, General provisions no. 7). The village of Disaster Resilient knows as (DESTANA) developed by the BPBD of Bengkulu Province, based on a program developed by the BNPB, as well as the following information:

Riak Siabun 1 di Kabupaten Seluma, Riak Siabun 2 di Kabupaten Seluma dan Lais di Kabupaten Bengkulu Utara. "Wawancara dengan bidang Pra Bencana, 16 Mei 2016).

"The village of Tough developed BPBD Province are 7 villages situated on 4 District/Region, namely" Padang Serai (Bengkulu City), Pondok Kelapa in Central Bengkulu Regency, Pekik Nyaring in Central Bengkulu Regency, Sumber Urip in Binduriang Subdistrict Rejang Lebong Regency. Riak Siabun 1 in Seluma Regency, Riak Siabun 2 in Seluma Regency and Lais in North Bengkulu Regency. "Interview with fields of Pre disaster, May 16, 2016)".

Development of Disaster Resilient villages is one of the efforts of community-based Disaster risk reduction. Disaster risk reduction-based Komunitasadalah any effort to reduce disaster vulnerability and threat to society, and increase capacity, preparedness, planned and implemented by the community as the main offender. In the villages, Disaster Resilient community actively involved in reviewing, analyzing, handle, monitor, evaluate and reduce the risks of disasters that exist on their territory, notably by making use of local resources for the sake of guaranteeing sustainable. (Perka BNPB No. 1 in 2012:16). 
Disaster Resilient villages developed with special purposes:

1) Protect people who live in areas prone to hazards daridampak-detrimental impacts of disaster;

2) Increase the participation of the public, especially vulnerable groups, in the management of resources in order to reduce the risk of disaster; 3 ) increase the capacity of institutional community in maintainer-an resources and maintenance of local indigenous knowledge for disaster risk reduction;

4) Increase the capacity of the Government in providing the technical resources and support for disaster risk reduction;

5) Enhance cooperation between stakeholders in the PRB, the local governments, the private sector, universities, Public Interest Group, community organizations and other groups concerned ((Perka BNPB No 1 in 2012:16): 17).

BPBD Province pioneered the Disaster Resilient Village in accordance with the allocation of the funds available. Gradually the village Toughened Disaster will be developed further in the other villages. Disaster Resilient villages in Bengkulu was done in stages, with the following activities:

1. Risk Assessment (Assess threat, vulnerability, risk and disaster capacity)

2. Planning and Contingency Planning PB villages

3. The formation of the PRB villages.

4. Increase the capacity of citizens and Officials in the PB

5. PRB design into the development plans of the village and the legalization of

6. Implementation of the PRB in villages

7. Monitoring, evaluation and reporting Program at the level of villages. (Interview with the field of Pre Disaster BPBD of Bengkulu province

\section{- Vigilant Disaster Village known as (KSB)}

Vigilant Village Disaster (KSB) is a community-based disaster mitigation model initiated by the social Ministry along with the community in order to accomodate the activities conducted by the disaster management community, formed in areas prone to disasters involving the whole way the elements that exist in the community. The main principle of implementation of KSB was the emphasis on self-reliance of the community. However, the support of other parties interested parties such as Government and private parties is still required. It is intended to motivate and reinforce the institutional disaster mitigation at the community level. (Social Ministry, 2011:9). KSB activities emphasize the importance of disaster preparedness. This means that the preparedness of society become a staple of KSB activity. Because with the preparedness of communities can plan an action to reduce the consequences of a disaster. However, the disaster has unexpected properties of (unpredictable) thereby kesiap siagaan alone is not enough. KSB team it is important to prepare the activities both before and at the time of the disaster, disaster, as part is inseparable between one stage with the other stages. (Social Ministry, 2011:15-16).

Activities at the stage of the disaster, is as follows (see in Social Ministries, 2011:14-20):

\section{Before a Disaster}


a. Planning activities before the disaster in the form of disaster risk estimates.

b. Preparing the Division/ KSB section Team

c. Compose and execute disaster relief simulation activities

d. Prepare Operational Procedures Standards

\section{When Disaster}

a. Prepare the task every section (team).

b. Help deal with disaster victims such as prepare-kan and or set up tents, field kitchens, integrated communications post, taking care of bodies, to help people who experience the disorder.

c. Making the report on condition of disaster and disaster victims to local Government (Social Department /Societal Institution, BPBD)

\section{The Post Disaster}

Post disaster recovery activities closely related to. During his recovery, we recommend that administrators and members of the KSB routinely held a meeting with other members of the public to know the needs and how the recovery against the impact of disasters. Before asking for help from outside parties, KSB team can identify resources that may be utilized for disaster relief.

Realization of the disaster preparedness village programme knows as (KSB) Social Service of Bengkulu province in 2013-2016 can be seen in the following table:

Table 6. Implementation Location of Disaster Preparedness Village of Bengkulu province in 2013-2016

\begin{tabular}{|l|l|l|l|l|l|}
\hline No & Years & Villages & Sub- District & Regions & Funds \\
\hline 1 & 2013 & Bintunan Village & Batik Nau & North Bengkulu & APBN \\
\hline 2 & 2013 & Baru Koto Village & Air Manjunto & Muko-Muko & APBN \\
\hline 3 & 2014 & Kungkai Baru Village & Air Periukan & Seluma & APBN \\
\hline 4 & 2014 & Abu Sakim Village & Pondok Kelapa & Central Bengkulu & APBD \\
\hline 5 & 2014 & Rawa Indah Village & Air Periukan & Seluma & APBD \\
\hline 6 & 2015 & Kota Padang Village & Manna & South Bengkulu & APBN \\
\hline 7 & 2015 & Rawa Indah Village & Ulu Talo & Seluma & APBN \\
\hline 8 & 2015 & Sidorejo Village & Kabawetan & Kepahiang & APBD \\
\hline 9 & 2015 & Sambirejo Village & Selupu Rejang & Rejang Lebong & APBD \\
\hline 10 & 2015 & Batik Nau Village & Ketahun & North Bengkulu & APBN P \\
\hline 11 & 2016 & Air Sebayur Village & Pinang Raya & North Bengkulu & APBD \\
\hline
\end{tabular}

Source: Data Victims of the Social Assistance Section, Social Department of Bengkulu Province

\section{- Vigilant Village}

Vigilant Village is a village whose inhabitants have the readiness resources and capabilities 
and the will to prevent and address health problems, disasters, an emergency and health independently. (promkes.depkes.go.id/homepage-3/\#). Vigilant Village is a real step health programs related to community empowerment of the village or region with target that villages community has the readiness of resources and capabilities and the will to prevent and address health problems, disasters, and an emergency independently.

The specific purpose of standby villages are as follows:

- Increased knowledge and public awareness of the importance of the health of the village.

- Increased alertness and preparedness village community against the risks and dangers that can cause health problems (disaster, outbreak, kegawadaruratan and so on)

- Improved environmental health in the village. The increasing ability and willingness of the villagers to help themselves in the field of health. (promkes.depkes.go.id/home page 3, July 4, 2016)

Vigilant Village is developed by Department of Health of Bengkulu Province, based on the decision of the Minister of health the number 567/Menkes/SK/VIII/2006 regarding the implementation of the guidelines for the Vigilant Village development. Based on such regulations then implemented the Village development all counties and cities, so that all villages and wards have been formed. Along with the expansion of the areas that impact the increase of the new County, district, village and region recently then need further development of Vigilant Village, as well as the statement of the health promotion of Bengkulu province as follows:

"In 2009, entire villages in Bengkulu province had become Vigilant Village along with the expansion, most villages or regions have not become Vigilant Village." (Interview with Promkes health office staff of Bengkulu Province).

The latest Ministry of health policy of Indonesian Republic, to develop the Vigilant Village by village and region active standby, based on the decision of the Minister of health of Indonesian Republic Number 1529/Menkes/SK/X/2010 about the guidelines of the development of villages and region active standby. (adaptation of the Promkes health service staff interview of Bengkulu Province). Through a policy of active standby villages, is expected to increase the quantity and quality as well as revitalize Vigilant Villages. The village or Kelurahan has active standby components (1) basic health services, (2) community empowerment through the UKBM development and encourage efforts community based surveillancebasically on community, emergency health and disaster relief as well as environmental health. (3) a life clean and healthy Behaviors known as (PHBS). (Ministry of health and Ministry of Interior, 2010:8).

Policy development the village and kelurahan active standby of Bengkulu province was set based on the decision of the Governor of Bengkulu number: W. 36. XII in 2011 on the establishment of an operational working group known as (POKJANAL) village and region active standby of Bengkulu province. In the autonomous region, order development of villages and kelurahan active standby is one of the mandatory Government Affairs regencies and cities. Despite this success the construction of the village and the village is also active standby is inseparable from the role of all parties ranging from the Central Government, provincial, region, district, village and other parties like civic organizations (Public 
Organization), the corporate world, as well as other stakeholders.

Disaster relief is a part of the village of active standby. Disaster relief at the village or region active standby, including pre disaster, while disaster and after disaster. Supply of PB and PRB socialized against the Manager of the village/region, where active standby in Standby Village Manager supply material from Poskesdes, there is the matter of disaster response and disaster risk reduction. (interview with Promkes health office staff). The capacity of disaster management into one aspect of the disaster preparedness Manager capabilities known as (Poskesdes), where any of the materials in the curriculum of training, there is material about disaster relief. PRB is an aspect of disaster relief that is also one of competencies of Vigilant Village. Then the competence of PRB also owned by UKBM (community based Health Business) another good in health centers, Pustu, as health office staff delivered as follows:

"The executor UKBM health and disaster relief, have the ability because it's already getting a provision about the PRB and the handling of the disaster. The village Health Post resources, Clinics, health centers and other UKBM have the ability actually ready harnessed in disaster management. Needs to be in consolidation is about the Division of labor and cooperation with stakeholders appropriately "(interview with health office staff of Bengkulu province).

Development of villages active standby provides cooperation Department and institution, ideally will improve community empowerment in managing villages active standby. The realization of the until recently then the bureaucratic structure supports the implementation of Pokjanal Village in standby, but haven't gotten to the real steps that can really enhance the activity of villages active standby. Active standby village into a great opportunity for the development of PRBBK, which already have extensive networks and potential, having already formed on the $93 \%$ of the entire village/ region in Bengkulu Province. PRBBK synergy on Desa optimally, it requires cooperation and organizing for the target optimization of PRBBK.

\section{- Community-Based Disaster Preparedness (KBBM)}

KBBM community based PRB is a program developed by the Indonesia Red Cross (PMI), with a team of volunteers who are known by the general public in Bengkulu and with the term SIBAT (community-based disaster preparedness). More about term Bengkulu society SIBAT PMI rather than the name of the program i.e. KBBM, because a lot of moves this SIBAT in PRB activities in the community.

KBBM program refers to the ICBRR (Community Based Integratd Risk Reduction), as a risk reduction effort that puts the community as the main perpetrator in the PRB. In order to program ICBRR can run well, then support is required both at the policy level or at the level of implementing. ICBRR need to be integrated in the structure of the PMI all levels, where there are elements of the Builder at the level of Administrators and Implementors at the level of Headquarters. ICBR program is part/sub work units than disaster management (PB) in all levels, so permanent and ad-hoc nature does not, as the duration of the projects. The integration of ICBRR in the structure of PMI is also the first step to maintaining continuity (sustainability), which at this early stage is still attempted with the support of donors, but ultimately the program will belong to the ICBRR and responsibilities of the local PMI to follow-up and develop it. (adaptation of the Final report of the city of Bengkulu, 3 KBBM 
funded by PMI Germany (German Red Cross), carried out on four (4) district/city of Bengkulu province Muko-Muko Regency i.e., Rejang Lebong, Bengkulu North and Bengkulu City, with the results of the program as follows:

"Program one year SIBAT, produces a device like a map of the village of PRB, volunteer groups of SIBAT, the document plan of activities, documents and infrastructure disaster relief such as number and owner of the truck and car in all villages or region, a variety of local community, profession and so on."

The number of SIBAT in each village as many as 30 people, who get training provision both theory and practice to be able to do the preparedness and emergency in the middle of community.

"PMI Volunteers or SIBAT amounted to 30 people for each Village, who was hired, might not trained armed with theory and practice, and then is given discretion to make disaster risk reduction program in accordance with local needs and conditions. PMI Province handed monitoring SIBAT and volunteers to PMI Region or City. "(Interview with staff PMI Bengkulu Province).

SIBAT as KBBM volunteer team mainstay PMI Region or City at this time, so in addition to spearheading the implementation of the PRB in villages respectively, are also involved in the activities of others, such as PMI deployed in the handling of the disaster that occurred in the village/region to another.

"SIBAT In Bengkulu city has been funded in 9 Villages, namely (1) Beringin Raya, (2) Pasar Bengkulu, (3) Rawa Makmur (4) Kampung Kelawi, (5) Tengah Padang, (6) Malabero, (7) Lingkar Barat (8) Padang Serai, (9) Teluk Sepang. SIBAT is spearheading PMI, whether pre or disaster handling in the event of a disaster. " (Interview with Mr. Saikoen, HW, PMI Bengkulu City).

Preparation, execution and reporting KBBM communicated directly with PMI Centre and team donors. Communication with the BPBD family in accordance with their needs.

"Implementation of SIBAT communicated with BPBD Province. Communication on the implementation of disaster mitigation program PMI always communicated by PMI with BPBD, either formal or informal. Communication tends to be done in a family (flexible) about the time, place and so on.

\section{- PRBBK Organized Public Interest Group}

PRBBK program implemented by the Public Interest Group known as LSM with the trends of funding by donor funds from foreign institutions or developed countries and be accelerated PRBBK development of Bengkulu province. PRBBK developed by these LSM which were done by LAYAK in Pasar Sebelat Muko-Muko Regency and PKPU in Lempuing Region and the decline of Bengkulu city that do PRBBK earthquake and tsunami with funding from UNDP in 2010-2011. PRBBK and climate change are also carried out by Kabahil Bengkulu as many as 30 villages, as the tsunami masterplan. (Adaptation of interview with the pre BPBD Disaster Areas of Bengkulu province).

PRBBK programme funded by UNDP, covers the following stages (interviews with PRBBK facilitator program UNDP)

1. Social mapping community (social mapping) 


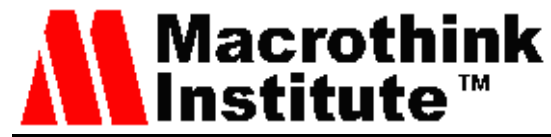

2. Assessment of vulnerability, risk and capacity

3. The establishment of a forum for disaster risk

4. The preparation of a Community action plan for disaster relief known as (RAK) and supported by the stake holders

5. Drafting of the rules of the village about disaster relief Plans

6. The preparation of Contingency Plans of Village Regulations

7. Documented local wisdom that is able to reduce the risk of disaster

8. Documented devices study social mapping and vulnerability in the form of PRBBK learning modules

PRBBK conducting earthquake and tsunami are done by all organizers of PRBBK against villages in the coast of Bengkulu. Risk reduction against earthquake and tsunami done ranging from the mapping of the situation or the drafting history of the disaster or search disaster vulnerability profile of villages, who would later serve as a data base in the analysis of vulnerabilities, capacities and measures for disaster risk reduction by utilizing all potential stakeholders in collaboration with the communities concerned. PRBBK program that specifically is only done on the coast in 2010-2015 is a program conducted by PMI (KBBM) and LSM that is Kabahil with the disaster program risk reduction and climate change funded by USAID, and programs funded by UNDP through implementation program by LAYAK, PKPU and WCC.

\section{- THE MODEL OF CONDUCTING COMMUNITY-BASED DISASTER RISK REDUCTION (PRBBK) FOR EARTHQUAKE AND TSUNAMI}

The action of the community-based Disaster risk reduction (PRBBK) of Bengkulu province, hosted by several Department and agencies with program names, stages and activities of each pattern is typical, for disaster management was carried out by the various agencies and the Department, either by the Government or private sector/LSM are sometimes in collaboration with Donor agencies. Practice this PRBBK delivered by Pre disaster Areas as follows:

"PRBBK conducted by various institutions, such as the KSB (Village disaster alert) from Social Service, SIBAT conducted by PMI, Village Department of health, LSM and PRBBK conducted by Village Toughened by BPBD. BPBD organises the village Toughened new beginning in 2012, while the program Department or institution PRBBK others have already started to do earlier. Before there was a BPBD institution, Department and other agencies did have funding and programs about disaster, so he has done PRBBK program continues to be implemented. PRBBK programs from the Department, agencies and Public Interest Group co-exist with Formidable Village BPBD. (interview with Kasi Pre Disaster Prevention Field BPBD).

Based on the system of organization of PRBBK by each institution, then it can be described as follows:

a. PRBBK Input

Input of PRBBK resting on three aspects, namely, implementing the Program and the community. PRBBK program that has been developed is a formidable Village disaster (Destana) with implementing BPBD, the disaster preparedness (KSB) and implementing 


\section{I Macrothink}

Social Service, Village/Region active standby with implementing health services, Community-based Disaster Preparedness (KBBM) with PMI, implementers and CBDRM by LSM. These programs have been developed in some regions and communities in Bengkulu. Socialization and development programs have been done either formally or informally, through international and national donor agencies, as well as using resources from both the Government, private or public.

Each PRBBK program good done by government agencies as well as Public Interest Group communicated with BPBD, with communication is still limited. PRBBK program conducted there is already a shared vision between the communities of stakeholders, but tends to be limited at the time of the program and those involved directly in the program.

b. PRBBK Process

1) The Process of Vigilant Village Disaster

PRBBK process as a level effort in strengthening empowerment for community is done through activities as follows (adaptation of Perka BNPB No 1 in 2012: 31-37).

a) Villages Risk Assessment (assessment of threats, vulnerabilities, and risk analysis capacity)

b) PB planning and Planning Contingencies villages

c) Forming the Forum PRB villages or region

d) Enhancement of the capacity of citizens and Officials in the PB

e) PRB Design into the development plans of the village and the legalization

f) Implementation of the PRB in the village/Region

g) Monitoring, evaluation and reporting Program in village/region level

\section{- $\quad$ The Process of Community-Based Disaster Preparedness (KBBM) PMI}

PRBBK Process as gradual efforts to empower the toughness to the community carried out the following activities:

a) Risk Assessment Village/Region

b) PB and planning Planning Contingencies villages

c) Forming the Forum PRB villages

d) enhancement of the capacity of citizens and Officials in the PB

e) PRB Design into the development plans of the village and the legalization of

f) implementation of the PRB in the village/region

g) Monitoring, Evaluation and reporting Program at the level of villages

\section{- Process of Village Disaster Preparedness Known as (KSB)}

Formation of Village Disaster Preparedness (KSB) is beginning with assessments to find out the readiness of the community to KSB. The clerk explains the complete program assessments and communicative with regard for local customs. The procedures for the formation of $\mathrm{KSB}$ as follows (the adaptation of the technical instructions of $\mathrm{KSB}$, 2000:29-32)

a) Community proposes activities for disaster risk reduction (PRB) to service/social establishments situated on the location of the KSB

b) local governments through social agencies/service identify and verify disaster-prone 
areas in the territory of the province or district/city

c) of local government through the Department of social agencies determine the location/KSB

d) After the location of the KSB set then done some activities that support the creation of $\mathrm{KSB}$ as follows:

- Social Ministries or local governments do counseling about disaster relief to the Community

- Community doing the selection to select the candidate Member

- Member of the team define and shape the management of KSB

- TAGANA do training and simulation

- Determination of KSB by local governments, Social Service/ District Head.

Stages of KSB formation through 3 stages, as follows:

a) Formation, Pre information dissemination activities at the level of policy makers (provincial) and stakeholders in disaster relief, such as BPBD, BMKG, Department of public works.

b) Implementation or deployment Guidance

- Formation information to $100-150$ people of the community who care about the problems of disaster

- Purpose of this activity is to get the team KSB totalling 30-50 people who really compact and solid. Because of this the future of KSB Team spearheading KSB

- disaster relief

- Training Simulation Activities, involving community that has gotten minimal counselling amounted to 100 people in the open field, aims to put into practice the knowledge of disaster at once how to act in the event of a disaster.

c) Under the establishment of monitoring by the parties that have the authority can perform monitoring at regular intervals.

\section{- The Process of Villages or Region Active Standby}

The implementation process of the active standby villages are as follows:

a) Endorsement SK villages active standby

b) Socializing villages active standby

c) Development villages active standby

Policy development of villages and region active standby of Bengkulu province was set based on the decision of the Governor of Bengkulu number: W. 36. XII in 2011 on the establishment of an operational working group known as (POKJANAL) village and Kelurahan active standby of Bengkulu province. This program started in 2001 and continues to be sustainable. In 2009 the whole village in the province of Bengkulu had already formed into the village of idle, however due to the expansion of the village, then by 2015 recorded 93.8\% which already formed the village of standby (Bengkulu Promkes Bulletin, issue 1 by 2015:4) the process of PRBBK villages active standby, carried out through the following activities a) Mapping disasters in villages, b) preparedness disaster, c) strengthening capacity, 


\section{Macrothink \\ Journal of Social Science Studies \\ ISSN 2329-9150 \\ 2017, Vol. 4, No. 2}

d) Reduce vulnerability, e) action (counselling, mentoring).

\section{- The Process of PRBBK of Public Interest Group}

Public Interest Group has a process for implementing the PRBBK, as LAYAK, PKPU, KABAHIL, and so on. PRBBK process carried out in implementing the UNDP program, with LAYAK, PKPU and WCC, with stages as follows:

a) Social history of Village mapping

b) An assessment of vulnerability, capacity and disaster risk villages

c) Formulation of a plan of action villages

d) Forming the Forum PRB

e) Drafting disaster relief Plan and Contingency Plan

f) Drafting of action

g) Plan Implementation Action

h) Simulation

As for the process of PRBB carried out KABAHIL, with programs from USAID, with the following stages (interview with Kabahil staff):

a) The socialization program to stakeholders

b) Mapping the history of the village/region

c) Drafting Plans and Disaster Contingency Plan Bearing.

d) Implementation of the Action

\section{- PRBBK Output}

PRBBK output in detail are as follows:

1) Forum or group of disaster risk reduction

a) disaster preparedness Group in the village of Disaster Resilient program developed by BPBD

b) Volunteer village or SIBAT (community-based disaster preparedness) for KBBM PMI program

c) Village disaster preparedness Team (team KSB) in Village Social Service disaster alert, powered by Midshipman disaster preparedness (TAGANA)

d) Forum PRB Region/Villages in the program of the PRBBK UNDP agreed by their respective communities

\section{2) Disaster Relief Plan and Contingency Plan}

\section{- PRBBK Outcomes}

Outcomes as the impact in PRBBK stages are as follows:

1) the village self-sufficient and resilient against the disaster (disaster Resilient Village outcomes)

2) KBBM PMI have the outcomes of community-centered Preparedness.

3) Village disaster preparedness have standby outcomes in facing the disaster.

4 PRBBK UNDP Program has Safety Culture outcomes

Based on the system of organization of PRBBK by institutions in the province of Bengkulu, 
then required program management and institutional strengthening by PRBBK BPBD Province, as well as the leadership of BPBD Province in the development of PRBBK either vertically (with BPBD district/city) or horizontal (with institutions organizers PRBBK). The driving factor in the form of leadership, coordination, synergy of policies and optimization of resources need to be focused to achieve outcomes PRBBK. Factors restricting PRBBK need to be managed into challenges and opportunities for the development of PRBBK during next steps with increased capabilities, performance and quality of institutional, human resource management and bureaucratic apparatus, apparatus and community siagaan kesiap and improved means of PRBBK infrastructure.

Based on the conducting process of PRBBK and analysis system of PRBBK, then the recommended Model is as follows:

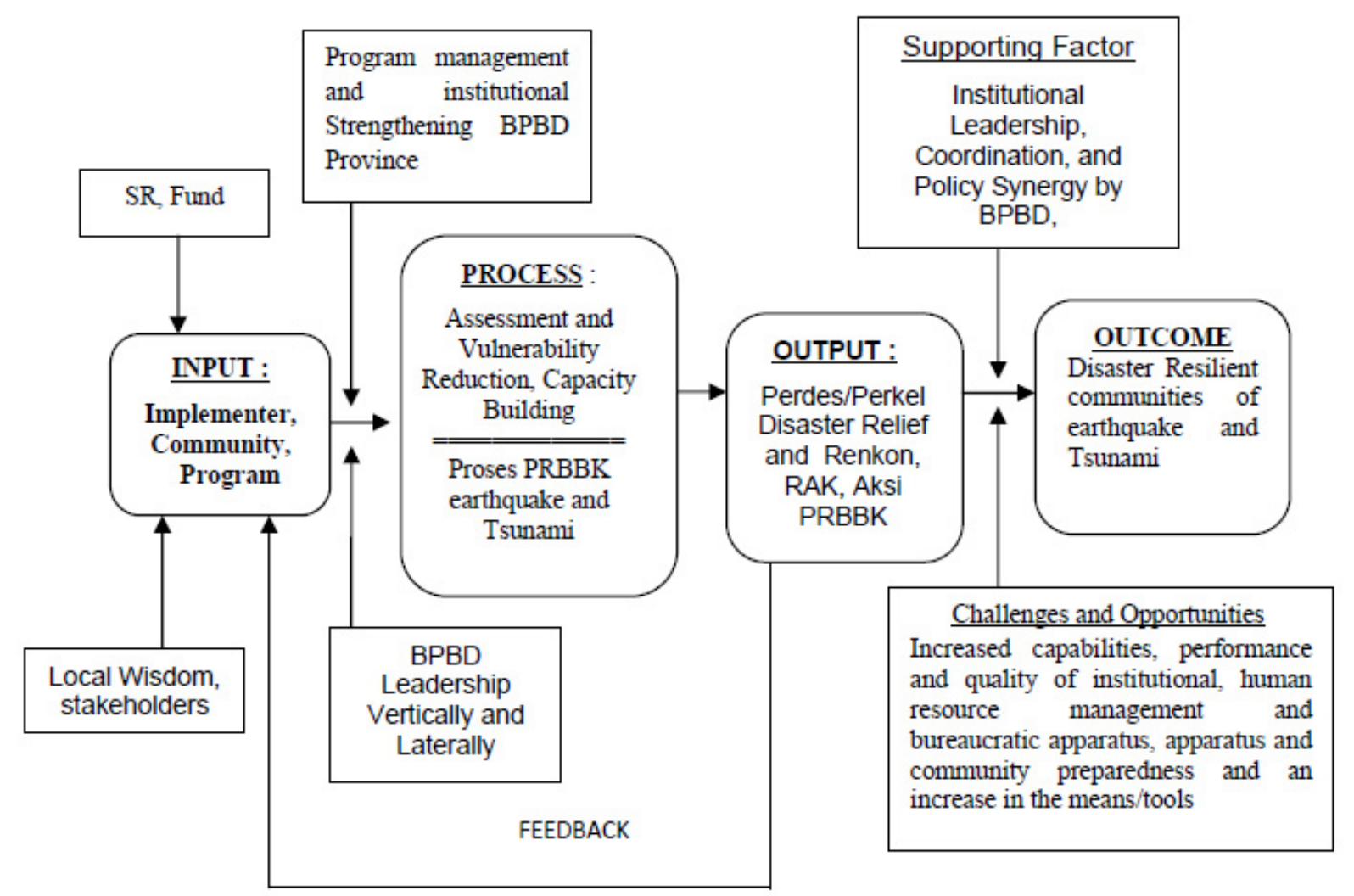

Figure 6. Recommeded Models of Community-Based Disaster Risk Reduction on the Earthquake and Tsunami in Bengkulu Province

\section{Conclusion}

Organization of the Begkulu province of PRBBK conducted by several institutions on the basis of a community of villages/region, which have been carried out at most locations with various models. The core process of assessment in the form of PRBBK threats, vulnerabilities and capacities as well as risk analysis along with action steps need to be developed more 
PRBBK evenly along with the follow up of the program continuously, so that learning outcomes achieved PRBBK effectively.

Community-based Disaster risk reduction in Bengkulu Province can realize kemandirin, culture of safety and disaster preparedness are effective when supported by the leadership of the BPBD, the optimal follow-up, sufficient bureaucratic capability. PRBBK development in the future needs to be improved with the leadership, coordination, synergy and optimization policy resources are focused to achieve outcomes PRBBK. Factors restricting PRBBK should be managed challenges and opportunities for the development of PRBBK during next steps with increased capabilities, performance and quality of institutional, human resource management and bureaucratic apparatus, apparatus and community siagaan kesiap and improved means of PRBBK infrastructure.

\section{References}

Bengkulu Ekspress, 9 Maret 2011: 5 (Koran)

Social Institution of Bengkulu Province, Data Seksi Bantuan Sosial Korban Bencana (Social Assistance Data for Disaster Victims), Dinas Sosial Provinsi Bengkulu

Dunn, W. N. (2007). Public Policy Analysis: An Introduction, Third Edition, Upper Saddler River, N. J: Pearson Prentice -Hall.

Ibrahim, A. (2009). Pokok-Pokok Administrasi Publik dan Implementasinya (Public Administration Subjects and Its Implementation), Refika Aditama, Bandung.

Ministry of Social Agency of Indonesian Republic. (2000). Technical Instructions Kampung Disaster Preparedness, Jakarta.

The Decision of Ministry of Health Number 564/Menkes/SK/VIII/2006 about the Implementation of the Guideline on Vigilant Village Development.

The Decision of Ministry of Health of Indonesian Republic Number 1529/Menkes/SK/X/2010 about the Guidelines of Villages and Region Development Active Standby

The Decision of Bengkulu Governor Number: W.36. XII Tahun 2011 on the Establishment of an Operational Working Group Known as (POKJANAL) Village and Region Active Standby of Bengkulu Province.

Lassa, J., Pujiono, P., Pristiyanto, D., Paripurno, E. T., Magatani, A., \& Purwati, H. (2008). Pengelolaan Risiko Bencana Berbasis Komunitas (Community-Based Disaster Risk Management), MPBI, Jakarta

MDMC Bengkulu, (2016). Head of BNPB Regulation No.1 in 2012

The regulatory agency's Chief Disaster Relief Area of Bengkulu Province Number 185 in 2014 about Regional action plan for disaster risk Mitigation (PRB) of Bengkulu province in 2012-2015, BPBD of Bengkulu Province Government.

PMI. (2014). Report on Community-Based Disaster Preparedness Programme (KBBM) of Bengkulu Province, Cooperation Germany Red Cross (GRC) and Indonesia Red Cross (PMI) PMI. (2014). The KBBM Final Report of Bengkulu City.

Quade. (1989). Analysis for Public Decisions, Elsevier Scienc Publisher, New York. 


\section{Macrothink}

Journal of Social Science Studies

ISSN 2329-9150

2017, Vol. 4, No. 2

Senge, P., Richard, R., Bryan, S., Charlotte, R., \& Art, K. (2001). The Fifth Discipline Handbook of strategies and tools for building a learning organization (Translated), Interaksara, Batam Centre, Batam.

UNDP and the Government of Indonesia. (2012). guide community-based disaster risk reduction (PRBBK), Jakarta.

\section{Copyright Disclaimer}

Copyright for this article is retained by the author(s), with first publication rights granted to the journal.

This is an open-access article distributed under the terms and conditions of the Creative Commons Attribution license (http://creativecommons.org/licenses/by/3.0/). 